\title{
LIRISMO CALLEJERO PARA PALADARES DE ASFALTO: NEORRABIOSO ENTRE LAS FIERAS
}

Fernando FIGUEROA SAAVEDRA

Universidad Complutense de Madrid ferfigsaa@yahoo.es

\section{$\mathbf{I}$} ntroducción: grafiti y poesía en el Madrid contemporáneo

Puede considerarse la irrupción de las plantillas del Dr. Hofmann en el Madrid del siglo XXI como la señal de que cierto espíritu de renovación empezaba a irrumpir en la monotonía mural de una democracia adormecida ${ }^{1}$. Alteraron un paisaje grafitero consolidado, pero repetitivo. No fue la causa, ni siquiera podría afirmarse que el único detonante que despertase de nuevo la fiebre por reconquistar el centro urbano, pero sí puede afirmarse que anunció la reapertura a nivel local del uso de la calle para manifestar otros discursos murales que no fueran las producciones asumidas dentro del Hip Hop Graffiti o las propias del clásico activismo político o social, ocasional o programado. Fue una nueva llamada a la creatividad pública fuera de los cauces económicos y los circuitos convencionales del arte, asumiendo las estrategias de los serigraffistas franceses de los ochenta, como Blek le Rat o Miss-tic.

Esto no supone que sucediese un relevo de propuestas o autores, pues fueron bastantes escritores de graffiti veteranos ${ }^{2}$, presentes o retornados, los protagonistas de ese Postgraffiti (Figueroa, 2006: 195-201; Abarca, 2010: 54-56), por lo que las nuevas y viejas propuestas estaban destinadas a coexistir y entablar un diálogo, más o menos cordial. Incluso esas otras manifestaciones murales precedentes tuvieron también su reflorecimiento después de una fase de depresión o «relax mural». Sin duda, la crisis del 93, como la del 73, contribuyeron a reactivar la calle ${ }^{3}$.

\footnotetext{
${ }^{1}$ Las primeras plantillas del Dr. Hofmann aparecieron en León en 2001. En Madrid hasta 2002 no se hicieron notar.

2 Aunque se haya fijado por la RAE el uso de la forma grafiti, en este texto se conserva su uso con doble efe cuando se hace referencia al movimiento Graffiti, su práctica y producción o a sus practicantes.

${ }^{3}$ La pintada política y social flojeó a partir de 1982, reactivándose desde 1986 en una creciente progresión que concluiría a finales de los noventa con la hegemonía de la pintada ultraderechista y anarquista en Madrid (Figueroa, 2004: 49-59). El Graffiti entró en crisis tanto en su vertiente autóctona, que decayó entre 1990 y 1993 (Gálvez y Figueroa, 2014: cap. 18), como en la hip-hop, que sufrió una depresión general y variable entre 1990/91 y 1993/94, entre 1990 y 1992 en Madrid capital (Figueroa y Gálvez, 2002: 120). El HHG remontaría claramente desde 1995 y el Graffiti autóctono no lo haría hasta mediados de los 2000, de manos de veteranos que retornaban a la escena tras años de parón. En lo que se refiere al Subway Graffiti, sufrió una contracción entre 1993 y 1994, pero se mantuvo más regular (Figueroa y Gálvez, 2002: 144). Por otro lado, la consentida presencia del muralismo social, a cargo de partidos, asociaciones culturales o vecinales, o colectivos de distinto orden, empezó a extinguirse de las calles madrileñas desde 1996, con la progresiva implantación y arraigo de una
} 
Por tanto, la eclosión del Stencil Art en Madrid (2002/03), agitado desde lo artístico y desde lo político con campañas como el Nunca Mais o el No a la guerra por grupos tales como Stop Wars, contribuyó y formó parte del repunte del grafiti surgido a mediados de los años noventa en la ciudad de Madrid, en consonancia con una efervescencia a nivel global del Stencil Art y el Graffiti, muy notable tanto en Europa como en América. En conjunto, se mostraba una inquietud general por plantear desde el grafiti contenidos, conceptos, reflexiones dentro de la exploración de una iconografía y un conceptualismo que conectase con todos, más allá de la definición de una estética o de una subcultura.

Ciertamente, la escena madrileña en los años setenta y ochenta supuso una reapropiación de la calle por la ciudadanía, simbolizándose en buena parte esta reconquista con el uso del muro como plataforma de expresión y comunicación, tras una fase de confrontación mural entre partidarios y opositores al régimen franquista, en la que la dialéctica política lo acaparaba prácticamente todo. Sin embargo, hay que matizar que una tipología muy ligada con lo poético, como la erótica o amorosa, persistió tímidamente durante el franquismo, dadas sus escasas implicaciones subversivas. Por consiguiente, el grafiti, como medio, es una constante cultural que testimonia los rasgos sociales de cada época, dependiendo de los factores endógenos que le dan forma y los exógenos que la conforman. Por esa razón, la eclosión del grafiti de firma en los años ochenta daba pruebas de la participación de los núcleos urbanos españoles en una nueva dinámica socioeconómica y deriva cultural, semejante a la de otros entornos de Europa o América, eliminada la interferencia de un régimen totalitario. La excitación grafitera era un síntoma más de un proceso de inculturación de la sociedad española dentro del modelo de sociedad de consumo occidental, con la globalización de ciertos modos sociales a través de los mass media (con gran peso del modelo estadounidense), formando parte dicho fenómeno de lo que podría llamarse la incipiente globalización suburbana o subcultural. Por tanto, ese festival de la pintada no era algo exclusivo de la escena madrileña, ni de la parisina o neoyorquina, sino que era una exigencia popular, generada por el sistema y la ordenación capitalistas. Respondía a un nuevo marco de relaciones humanas en el que el grafiti servía para mostrar el desencanto o la adhesión, y cuyo éxito como forma de expresión generó su masificación y extensión. Por eso, se daba en aquellos lugares que compartían una órbita político-económica común y un contexto cultural emparentado por el mercado cultural, en especial con naciones americanas o europeas que salían de la dictadura y asumían la democracia parlamentaria como forma de gobierno, y que adolecían de un retraso respecto a la prístina eclosión grafitera de los años sesenta y setenta, a la que se fueron sumando entre los años ochenta y noventa.

Las décadas posteriores a la posguerra mundial y, en especial, con la eclosión en los años cincuenta del Rock \& Roll, contrajeron la consagración del grafiti en las ciudades modernas de la segunda mitad del siglo XX como un medio de expresión popular y juvenil (Figueroa, 2014: 158-306).

política y legislación antigraffiti a nivel municipal (Figueroa, 2013a: 388-389), iniciada y sistematizada durante la concejalía de limpieza de Esperanza Aguirre, con implantación del Anti Graffiti System en 1990, y enarbolada como frente político por Ana Botella desde 2007, durante la concejalía de medio ambiente y la alcaldía. 
Este arraigo se ha mantenido desde los sesenta hasta hoy en una progresión constante, articulándose su práctica al hilo del desarrollo sucesivo de los movimientos sociales y estético-musicales que refrescaron y redefinieron su uso tradicional hasta alcanzar un plano artístico. Además, se ha integrado dentro del circuito económico, lo que ha permitido convertirlo en un endemismo de la modernidad, con la ayuda añadida de una sistemática y costosa represión que remata su integración dentro de la maquinaria económica del capitalismo neoliberal. Sólo obstáculos de índole política, como el totalitarismo, interfirieron en su surgimiento, aunque por otro lado lo potenciaban. A través de él se expresaba el desajuste o la disconformidad del individuo frente a los perjuicios generados por la modernidad, pero también, en estrecha relación con el grado de libertades, el grafiti podía representar lo contrario: una celebración cívica o exaltación vital dentro de una situación extraordinaria o de un entorno tolerante (aspecto que se ha ido haciendo más común en el segundo tercio del siglo XX). En esa encrucijada, los poetas urbanos han ido establecido su peculiar relación amorosa con los muros, desde la intimidad de los interiores hasta los recoletos callejones o jardines, o los muros exteriores cuando la fruición subversiva o el festival democrático permitían reclamar o ratificar la conquista de la calle como un espacio poético o, lo que es lo mismo, un espacio de libertad política. Esta exaltación fue muy patente en el Muro de Berlín, constituyendo la poesía un contrapunto espiritual al totalitarismo materialista del bloque comunista y una llamada de atención al bloque capitalista a favor de una tercera vía más humana y fraterna.

\section{Precedentes activistas de Neorrabioso}

En esa «puesta al día» del grafiti en España, repararemos en el grafiti de leyenda o su subtipo de leyenda ingeniosa, entendido como una expresión textual del pensamiento, filosófica o poética, en definitiva, una llamada a la reflexión y, si acaso, un impulso para la concienciación o activación individual o colectiva (Kozak, 2004: 82-83). Estos textos que, por lo común, se mueven en un cuestionable «anonimato», la firma original mediante pseudónimo o nombre propio, la firma atribuida o la falsa atribución (Gándara, 2002: 55-71), aportan la impresión viva de asistir sobre el muro a la visión de un subconsciente urbano agitado por deseos y tabúes, caprichos y necesidades; incluso, de contener y salvaguardar una conciencia cívica o espiritual de la sociedad de base. Su valor como mensajes se funda en la expresión de un pensamiento, por lo común a la espera de ser leído por un receptor sin que - y eso es muy importante para distinguirlo de los grafitis funcionales, con un potencial comunicativo puntual y caduco, o que sirven al marcaje territorial - su contenido pierda su cualidad expresiva, por lo común emitida con vocación universal, aunque con el paso del tiempo pierda legibilidad o se alteren los contextos que permitan su correcta interpretación original y se reasignen otros significados, o se pierda definitivamente cualquier posibilidad de lectura, si no han desaparecido antes (Gándara, 2002: 52).

Aunque existen determinadas ciudades y momentos en que esta tipología parece darse con gran profusión y fortuna cultural, como el París sesentaiochista (Besançon, 1968) o el Buenos Aires de entre 
1983 y 1987 (Kozak, Floyd, Istvan y Bombini, 1990: 14-15, Kozak, 2004: 128-138) ${ }^{4}$, es una tipología habitual que ha llamado la atención tanto de viandantes en general como de personas sensibles al hecho literario. Este es el caso de los poetas, y de un tipo de poeta vinculado con la fibra urbana. Por ejemplo, en 2001 se publicó una recopilación seleccionada de grafitis de leyenda aparecidos en el Metro de Madrid por parte del poeta y cantor argentino Indio Juan (Indio Juan, 2001), fundamentalmente de los años ochenta y noventa. Éste, al modo de un Brassaï en el París de los años cincuenta, había ido reparando en ellos y los había anotado desde que llegase exiliado a España en 1974. Este libro es una muestra más del afán documentalista de la pintada que hasta podía llegar a tocar el aspecto estético. En este caso llamó la atención de un cronista del pensamiento y el sentimiento que se permitía considerar la pintada como un campo literario, público, colectivo y polifónico (Gándara, 2002: 57-58). Otros autores españoles también las recopilaron al albor de la agitación de los años setenta, tanto en Barcelona (Gan, 1978) como en Valencia (Arias, 1977), con un enfoque más sociológico y no artístico o filológico.

Con simplemente estos antecedentes, podemos darnos cuenta fácilmente de que el caso que nos ocupará de Neorrabioso no es único, pese a su singularidad, popularidad y reverberación mediática. Como él, hubo y hay otros con una actividad puntual, ocasional, constante y, raramente, compulsiva. Hay que recordar que es esa constancia, junto a la concreción de una comunidad de perseverantes, una característica crucial que distingue sobremanera las escenas grafiteras de la segunda mitad del siglo XX frente a otras épocas. La aparición de personajes como los escritores de graffiti o los artistas urbanos constituye una nota distintiva del paisaje urbano moderno. Esa especialización vital, por tanto, es un síntoma más que delata las carencias comunicativas y la deficiente imbricación comunitaria en las urbes modernas, el pertinaz aislamiento de nuestra sociedad de masas, pero también es un intento disperso de superar esa traba que, frecuentemente, no entraña que entre sus ejecutantes haya un conocimiento previo de sus existencias, produciendo una disparidad de propuestas. Por otro lado, su progreso nos advierte de la validez cultural de este medio de comunicación marginal a colación del simulacro de los mass media y de los procesos de tecnologización y espectacularización de las manifestaciones culturales y las relaciones sociales.

Aunque la sentencia grafiteada nos retrotrae al mundo recoleto de las celdas, las letrinas, las escuelas, las tabernas, los camerinos, etc., forma parte del imaginario estético de la bohemia y el underground, de la esfera iconoclasta o de reivindicación emocional en un entorno racionalizado o reprimido, de la esfera gamberra, excéntrica e irreverente de los ritos de paso juveniles o, a veces, de

\footnotetext{
${ }^{4}$ La profusión de ciertas frases o lemas, por medio de la música, el cine o el grafiti en su faceta más popular o underground representa una conexión con un espíritu de época, con las claves de una mentalidad compartida, generacional o local. Esto fue muy evidente cuando algunos grafitis de los sesenta de Europa o América se convirtieron en memes internacionales, debidamente traducidos y adaptados. Gracias, en parte, a la publicación de libros recopilatorios de grafitis o álbumes fotográficos, que vencían la transitoriedad o carácter efímero del medio. El caso más paradigmático es Les murs ont la parole, de Julien Besançon (1968), sobre el Mayo del 68. Así pudo registrarse su perduración en la España de la Transición, llegando su eco hasta el 15-M. Esta reproducción y recarga simbólica conecta con una interpretación del grafiti como plataforma de cohesión social, como marco de proyección e irradiación de ideas comunitarias. Más tarde, la difusión digital ha superado en mucho el ritmo de propagación de los textos grafiteados, aunque también es tan alto ritmo de renovación que su resonancia en la calle es más fugaz.
} 
la esfera asocial de las burbujas creativas de los outsiders. Entre las tabernas y los callejones, las letrinas y las estaciones de metro, se erige la contestación frente a la hipocresía religiosa y la moral burguesa, con imágenes tan emblemáticas como los garitos parisinos de los años cincuenta, a ritmo de jazz y al albor de la cultura Beatnik, donde escribir, dibujar o pintar en las paredes era toda una declaración de principios. Su proliferación fue hija de la divulgación cultural, de una manera de ver el mundo hermanada con la revolución musical del siglo XX y el asentamiento de una cultura alternativa, vertiente de resistencia de la cultura popular.

En ese tiempo su parangón en Madrid fue inexistente a efectos prácticos en una sociedad represiva, en la que por otra parte la poesía no dejaba de ser política y moralmente sospechosa, si exceptuamos el irredento reducto de la latrinalia con su contundente sesgo escatológico ${ }^{5}$ o el de las inocuas celdas penitenciarias ${ }^{6}$. Ese influjo excéntrico, propio de bohemios y enfants terribles, sólo se dejó sentir en la España franquista a modo de evocaciones ambientales, como puede aún verse en el mesón de piano de las Cuevas Sésamo, nido de artistas liberales y subversión antifranquista, sito en la madrileña calle del Príncipe.

Sin duda, fue con el declive del franquismo, con la llegada de nuevos aires de libertad al son del rock urbano, cuando surgirían pintaparedes como Los Siete Magníficos del barrio de Vallecas (Rodríguez, 2002: 92). Un grupo que en septiembre de 1976 decidió escribir frases en los muros con la intención de provocar y subvertir el orden establecido, así como para quebrar los dogmatismos de la izquierda política. Eran ejemplos de la puesta en marcha de actitudes ligadas a la Contracultura americana y europea, impulsadas por un espíritu hippy o libertario afín a iniciativas como los provos, los indios metropolitanos, los yippies o los punkis, en contraposición con las viejas formas de hacer y pensar alto y bajoculturales. Era hora de dejar mensajes cargados de ironía y no de proclamar los tradicionales eslóganes doctrinarios de los movimientos obreros ${ }^{7}$. Quizás ese uso de la sentencia

\footnotetext{
${ }^{5}$ Aunque se da la poesía en la latrinalia, con un tratamiento sentido y hasta romántico o existencial, es habitual que tienda hacia la parodia o lo chabacano, con una clara pulsión iconoclasta o profanadora. Así se pudo observan en los servicios públicos masculinos y femeninos de la Universidad Complutense de Madrid en 1998 (Figueroa, 2004: 71-72, 76, 78-79, $82,86)$.

${ }^{6}$ Se ha observado la reproducción, más o menos literal, de poemas o letras de canciones por reclusos en sus celdas como uno de esos rasgos propias de la resistencia o reivindicación de lo humano. Por ejemplo, en el caso de la Cárcel de Carabanchel, se pudo localizar desde la cita de letras de Extremoduro hasta versos de Rafael Alberti (Figueroa, 2013b: 304-305). Así pues, se enlaza su uso con estrategias que tratan de conjurar el embrutecimiento o la deshumanización, reclamando con refinada rebeldía la dignidad perdida o en peligro, o sea, sirviéndose de ella como escudo frente a la patologización de los sujetos presos. Una diferencia sustancial entre la poesía carcelaria y la callejera es que la primera tiende hacia la autorreferencia, la autobiografía, por el gran peso del factor ambiental y el aislamiento, mientras que la segunda impulsa hacia el enfoque social y permite sublimar la autorreferencia hacia significados más universales. Sin embargo, el sentimiento del mundo como cárcel, en parangón con el concepto foucaultiano de sociedad panóptica, hace que temas como la muerte social, o el ansía y esperanza de un tiempo de libertad se prodiguen del mismo modo.

${ }^{7}$ Batania participa de la vivencia del arte como agitación desde el individuo, mani-fiesta-acción o acti-vivismo. En sus coordenadas libertarias, el artista no debe pertenecer a una organización, debe estar libre de imposiciones y permanencias que conducen a la sociedad casi siempre a la necrosis, el dogmatismo y la burocracia. Dice: «el (r)evolucionario pierde la erre en el momento que cruza por la puerta del Parlamento», una afirmación que subraya el valor de la calle y la valía de su nutrimento vital y moral. Batania cree que «las ideas buenas se abren ellas mismas el camino, solo hace falta formularlas sin ningún afán proselitista. [...] si una idea llega al poder, acaba convirtiéndose en una mala idea» (Go!, 2015: 31). Evidente por cuanto que durante siglos ésa ha sido una regla fundamental del desarrollo de la cultura popular, al margen de dirigismos procedentes del poder (propaganda), y se mantiene viva hasta que se anula o absorbe por la alta cultura y, en nuestra época, por el mercado (publicidad).
} 
pública sobre los muros no fue más que una anécdota dentro de un uso desperdigado por otras esferas, tales como las pintadas rockeras o punkis, o las citas propias del entorno carcelario, marcadas por la particularidad de una arquitectura represora ${ }^{8}$. Pero es evidente, que pese a la posterior hegemonía del grafiti de firma en su vertiente autóctona o desde el imperativo de la reproducción del modelo neoyorquino, la autoafirmación individual conllevaba la exploración de otros medios para singularizarse de y entre la masa. Ese aspecto es muy interesante de resaltar, pues en un momento de arraigo y masificación, algunos escritores de graffiti sintieron la necesidad de acompañar sus firmas con frases que completasen o manifestasen algo más de ellos que el mero diseño de una firma, un estilo gráfico o una manera de hacerse ver.

Por lo común serán escritores autóctonos, como Rafita, Glub o Remebe, los que incluyan esos lemas personales, aforismos o llamadas a la trascendencia con los que abrían su interior al espectador o fortalecían su máscara social, con guiños a anécdotas personales. Posiblemente, porque el situarse al margen del imperativo de la mímesis neoyorquina les permitía innovar en esa dirección. Incluso algún autóctono escribía poesía, como el mismo Muelle, cuya afición no debía de estar muy desligaba del mundo musical al que pertenecía, pues ha sido notable el desarrollo lírico de algunas letras del Rock o el Pop. Alguno llegó a abandonar la calle para enfrascarse en la actividad literaria, como es el caso de Larry 88, que se dedicó a la poesía entre 1990 y 2003, bajo la influencia de Bukowski o Ginsberg. En ese último año retornó a las calles con el boom del Stencil Art, incluyendo en ocasiones textos, bajo el nombre de Einsamkeit Neuroemesis o Einsamkeit. La senda del dinosaurio ${ }^{9}$. Respecto a que esas frases tuviesen un ribete social, no puede negarse que, aparte de contribuir con «decoraciones» en los años noventa en casas okupas o centros sociales, el escritor de graffiti o el artista urbano puede manifestar a título personal su adscripción política con la inclusión de ciertos iconos o estilemas gráficos, o traslucir en el sesgo o trasfondo de sus comentarios o representaciones visuales una enfoque social. Igualmente, el apoliticismo, hijo del pasotismo, de los años ochenta ha ido dejando paso a una paulatina repolitización del grafiti y, por tanto, del Graffiti y el Arte Urbano desde la segunda mitad de los noventa.

Paradójicamente, el mismo Writing neoyorquino también ofrecía la posibilidad de incluir frases de contenido social, pero una transmisión tamizada, superficial y pobre durante su introducción en España hizo que sus escritores desconociesen esa vertiente y no estimasen a priori que ese hábito de algunos autóctonos fuese compartido por el Hip Hop Graffiti. Más tarde, el hábito de frasear se fue normalizando mediante frases o lemas con un estilo peculiar, que remitía a las rimas, comentarios o arengas de los MC's, los cuales podían llegar a girar en torno al activismo social y político. La construcción compositiva de las piezas del HHG permitía esas muestras textuales de corte lírico como

\footnotetext{
${ }^{8}$ En cierta medida, al igual que algunos autores consideran que es en el grafiti donde se puede desarrollar un arte verdadero, algunos consideran que ciertas tipologías grafiteras permiten una literatura libre. Kozak (2004: 81) considera que es en el ámbito carcelario donde se produce una literatura del verdadero límite, señalando cómo Eduardo Gudiño («Graffiti», 1969) estimaba que el grafiti carcelario era el más cercano a la verdadera poesía. Sin duda, un reflejo de la apertura de parámetros neorrománticos que anunciaban la Posmodernidad.

${ }^{9}$ Algunos de sus textos se podían ver en una página web [http://www.oocities.org/stencileinsamkeit, última consulta, 216-2016].
} 
aderezos del rótulo central, con una discreción mayor que en el caso de acompañar a una firma. Digamos que, en ese caso, su inclusión debía subrayar el sujeto-objeto del enunciado, por lo común el nombre del escritor, leitmotiv de su pieza. Se reafirmaba con ello su papel protagonista, al modo del diseño de las portadas de cómics o de los carteles de cine, en los que el título se acompaña de un subtítulo u otros créditos. Hasta resulta curioso subrayar un cambio sustancial desde la perspectiva histórica: si antes era habitual que una frase se acompañase de una firma que la suscribía, ahora era la firma la que se acompañaba con una frase, que refuerza la solidez de lo que se presupone que hay detrás de esa firma: una personalidad. Más aún, al ser menos discreto que su inclusión en una pieza. Una inercia propia de la motivación del tagging y el Graffiti de reafirmar y singularizar la identidad personal por medio de la construcción de un alter ego peculiar, del que tiene que quedar claro que todo dimana.

Ya sea para destacar dentro de su comunidad o para fortalecer el vínculo con ella, ya sea para alimentar una inquietud personal o por establecer una comunicación más rica o plena con el viandanteespectador, los escritores de graffiti y otros autores anónimos que escriben esporádicamente citas o pensamientos se configuran en precursores de una tendencia esporádica, no generalizada, pero posible; con un potencial latente propenso a la eclosión festiva en un tiempo de libertad o en una eclosión subversiva en tiempos de reacción u opresión ${ }^{10}$. Su agudización tras cruzar el umbral del siglo XXI, a diferencia del proceso ochentista, bien podría entrañar una respuesta a la consolidación de una visión negativa del entorno a nivel local y a la suma de distintas voluntades a un clima de disidencia sistémica a nivel internacional, concentrado en ciertas individualidades o colectivos, ejemplos vitales, que aprecian el valor de la expresión emocional e intelectual dentro del diseño de una sociedad alternativa.

De ese clima concreto que se fue generando desde el No a la guerra de 2003 hasta el movimiento 15-M de 2011 se nutre el nervio de las acciones de Batania Neorrabioso ${ }^{11}$. Al son de la reaparición o revival del sesentaiochismo, la erupción callejera de este tipo de pensamientos o lemas, más allá de la retórica tradicional de la pintada política, que trasluce la nueva toma de conciencia de las trampas y

\footnotetext{
10 Batania se moverá entre una visión dionisiaca y otra trágica, un totum revolutum temático que reflejará su discurso ácrata, antinacionalista, ecologista, antimilitarista, cosmopolita, iconoclasta, etc.: «Liberqué, igualiquién, fratenicuándo», «Esta democracia sólo es un palillo de dientes», «Las clases medias no tienen ideas enteras», «Lleváis grumos de sangre en las corbatas», «Menos infantería y más infantilería», «Inmigrantes, vosotros sois el mar de Madrid», «Hace un tiempo espléndido para otra Bastilla», «La noche y la rebeldía siempre vuelven», etc. Contrae, al tiempo, la renuncia al modelo de vida convencional o ajustado a la corriente unidireccional de una sociedad capital-consumista: «Mi vocación soy yo», «Me niego a vivir en serio y en serie», «No seas standard», «Te hacen la vida otros», etc. Apela también al retorno del ser salvaje, a la naturaleza, como metáfora de la libertad humana: «Quiero ser búfalo», «Tus caballos se mueren por falta de viento», «Reniego de los humanos: solicito un pasaporte de pájaro», «iLo que lucen las dalias sin saber de botánica!», «Siempre que nieva tengo cinco años», «No somos perroflautas, somos tigreflautas», etc. Enaltece estados de ánimo extremos, como contrapunto al estado de cosas o al simulacro de seguridad simbolizados en la falacia de la estabilidad. Incluso, lo hace como resistencia social, enfrentando la imagen del poeta como cuerdo en conflicto con una sociedad productora de delirios caníbales. En cierto modo, esa temática está impulsada por la inquietud sobre su propia situación psicológica, la exaltación de una ubicación fronteriza como situación idónea para una plena conciencia de la existencia real y replantearse el hecho vivencial, a pesar del sufrimiento que pueda contraer: «Triunfan los equilibrados, pero prefiero a los equilibristas», «Hay que enloquecer ya: que luego será tarde», «Pájaros en la cabeza los tenemos todos, pero vivir es sacarlos a volar», «Me automedico: escribo», etc.

${ }^{11}$ El propio Batania se aficionó a recopilar frases generadas por la creatividad lingüística del 15-M, que exponía en su blog (TeleK, 2012).
} 
embauques del sistema, del poder del lenguaje y del juego de espejos, y que azuza la confrontación desde el individuo y la colectividad contra un modelo cultural que no satisface su feliz desarrollo, ni siquiera el cumplimiento de las expectativas que promete. Es más, significa la revalorización de la poesía urbana como bandera de cambio cultural. Cuando los situacionistas decidieron sacar la poesía a las calles a través de una poesía sin poema (Kozak, 2004: 53), sentaron un precedente que no dejaría de estar latente en la subcultura o cultura alternativa, tanto como postura de combate como si se adopta como posición de resistencia.

Sin embargo, insisto en la idea de que la presencia de la poesía en el marco urbano sirve usualmente de contrapunto festivo ${ }^{12}$, de festejo fraternal de la vida, de garantía de desarme agresivo de una propuesta, pero también de compromiso activista con la utopía como pretexto para alcanzar un estado de desarrollo pleno del hombre y la sociedad. El cariz emotivo y lírico, tantas veces asociado con el espíritu juvenil, con las subculturas o con los viejos o, más aún, los nuevos movimientos sociales es toda una declaración de principios y engarce con el impulso vital y gregario.

Finalmente, podemos destacar dos precedentes notorios como propuestas con una fuerte entidad y una comprobada constancia y, por tanto, exponentes de una tendencia que da frutos dispares o influyentes en otros agentes cuando tienen noticia de ellos. Ambos casos nos ilustran acerca del renovado uso de la poesía callejera como motor de transformación social en el tránsito del siglo XX al XXI, y anteceden a la propuesta individual de Neorrabioso y su eco mediático.

El primer caso sería Mujeres Creando, un colectivo anarcofeminista de La Paz (Bolivia) que desde 1993 desarrolló una viva y comprometida actividad de publicaciones y grafitera antipatriarcal, antirracista, descolonizadora y en contra de la inhumanidad del neoliberalismo. Aún sigue activo desde

\footnotetext{
12 Hay que distinguir el efecto producido por un grafiti poético en un entorno urbano del aparecido en un entorno rural o natural. Esto se refleja en una serie de pintadas realizadas por el Dr. Hofmann en la Patagonia (2006), sobre distintos hitos del paisaje, levantados por la mano humana a lo largo de $15.000 \mathrm{~km}$. de carretera. Sus frases cortas resaltaban, pese a su aparente intrusismo en un espacio impropio, la evocación del potencial humano que renace del reencuentro con la inmensidad de la naturaleza, la evidencia de su entidad natural frente a lo sublime, en el marco de lo que puede establecerse como una metáfora contemplativa de la vida como búsqueda-reencuentro o viaje iniciático (trip) [http://www.drhofmann.org/actualidad/?p=177, última consulta, 21-6-2016].

El road graffiti o grafiti de carretera es habitual como una variante o prolongación del getting-up del grafiti de firma, que ha conllevado que algunos de sus autores establezcan un parangón entre la deriva geográfica y su propia construcción o exploración personal, en un marco sin duda más solitario y que ensimisma su vivencia, a pesar de acrecentar el efecto de shock estético a ojos de otros viajeros. Este fue el caso de Iñakissur (Ignacio Alvero), un escritor de graffiti vinculado con la cultura Rock y que ha desarrollado una actividad musical, tirititera y poética - Soñando que estoy despierto (1995) y Otra vez soñando ke estoy despierto (1997)—, en la que comparte enfoques con Batania, tales como el antimilitarismo, pesimismo junto a optimismo, transgresión y diversión, la ecología, etc. (Gálvez y Figueroa, 2014: cap. 9). Ambos son igualmente de origen rural.

Es interesante en este caso, resaltar el binomio rock-carretera, propio de la Contracultura americana, deudora del concepto del viaje como metáfora de la vida, como sucesión de experiencias que ofrecen un autoconocimiento interminable y que contrae la fusión con la vida y la naturaleza, a través de la exploración de lo humano en uno y del propio ser en los otros en una vertiginosa y vitalista espiral.
} 
un posicionamiento periférico, pudiéndose seguir sus actividades en Internet ${ }^{13}$. Ha actuado fuera de su país, en Europa y en España, incluida Madrid.

Las claves de sus pintadas, que bautizan como grafiteadas, por ser grafitis combativos, son varias y se emparentan espiritual e ideológicamente con las propuestas sesentaiochistas, concentrándose en el discurso de género y la sexualidad. No obstante, como sucede en la historia del Arte Urbano y del Graffiti, no se puede hablar de un continuo uniforme en casi medio siglo de desarrollo, sino que cada episodio acusa ciertas matizaciones y es por eso que el activismo mural de los años noventa, 2000 o 2010 se enfrenta a un marco de circunstancias diferente al de los sesenta, setenta y ochenta, especialmente en el aspecto técnico y táctico. Por ese motivo el grueso de sus planteamientos podría compartirse por los hippies de los sesenta o por Batania Neorrabioso, como se refleja por Julieta Paredes y María Galindo (Paredes, 1999: 2-22):

-Vinculación espiritual con la utopía y la revolución desde el propio cuerpo.

-El espacio público es un espacio de difusión y el grafiti una acción inmediata y directa sobre un espectador despojado de estatus.

-La pintada se asume como medio de expresión del activismo social y personal, además de formar parte de una acción más compleja, de un performance enfocado a la concienciación social y al activismo

-La lucha incluye también un valor festivo y un aspecto amoroso, alejado de su vivencia como una experiencia militarizada. Su lucha es un compromiso con la vida, es creativa no destructiva, la pintada embellece, no es vandalismo.

-Cuestionamiento de las convenciones sociales y sexuales, el concepto de suciedad urbana y la denuncia de la arquitectura cuadrangular ${ }^{14}$.

-Empleo del color y la caligrafía cursiva como distintivo, como manifiesto de su singularidad y reivindicación colectiva.

-Se consideran pintoras y seleccionan el soporte, evitando en lo posible paredes recién pintadas y siempre si son monumentos.

El otro caso es Acción Poética, surgida de manos del poeta Armando Alanis Pulido en Monterrey (México) hacia 1996, con la pretensión de compartir la poesía en la calle con el uso del muro y la

\footnotetext{
${ }^{13}$ Mujeres Creando se sirvió de la publicación de fotografías en formato de postales o en libros para difundir sus performances y grafiteadas, para luego crear un portal de Internet y producir vídeos, afectada por la transición de una cultura textual a una digital. Su web es [http://www.mujerescreando.com, última consulta 21-6-2016]

${ }^{14}$ Este punto de disidencia cultural contra la arquitectura y el urbanismo racionalista y el modelo social que se desprende de él, fiel a los principios de popes como Adolf Loos, es una constante de la Contracultura, desde los postulados del arquitecto Friedensreich Hundertwasser, expuestos en manifiestos como «Verschimmelungsmanifest gegen den Rationalismus in der Architektur» (1958) o «Dein Fensterrecht - Deine Baumpflicht» (1972), hasta el mediometraje The White Bus de Lindsay Anderson (1967), pasando por la canción protesta Little Boxes de Malvina Reynolds (1962). Ese factor físico unifica y explica en gran medida el surgimiento mundial del Graffiti en ciudades tan distantes como Filadelfia, Nueva York, París, Berlín, Sâo Paulo o Buenos Aires. Por otro lado, la excitación del grafiti urbano constituye una consecuencia inevitable de la percepción opresiva de la arquitectura y la ciudad moderna como sociedad panóptica.
} 
pintura. Con ello se quiere compartir la poesía, hacer sentir y pensar a la gente fuera del contexto publicitario y humanizar el paisaje urbano. Esta «campaña internacional» está bastante regulada, sin que se promueva su ubicación en la ilegalidad. Su iniciativa fue creciendo hasta el punto de articularse en una especie de movimiento internacional, cuyos participantes deben respetar ciertas reglas para ser considerados dentro del proyecto. Desde el año 2012 empezó a difundirse por multitud de ciudades de Argentina, Chile, Perú, Paraguay, Bolivia, Ecuador o Uruguay, incluso de España ${ }^{15}$.

Ambas iniciativas reivindican la poesía, reclaman su presencia pública y propagan su ejercicio, en un gesto que delata un cariz de resistencia contra una inercia social que aboca a la poesía a su extinción. Si bien la prioridad de Acción Poética es conservar la poesía, incentivando un público amante de la misma, sin cuestionar ni arremeter contra el sistema, para Mujeres Creando la poesía es un arma coherente de sensibilización y lucha contra un sistema que pone en peligro su alma. Mientras Acción Poética es reformista, Mujeres Creando es revolucionario y, por eso, no teme violentar el espacio coartado, pues es un símbolo de liberación. En este planteamiento, Batania hace suyas las palabras de Antonio Gamoneda, según las cuales la poesía no cambia el mundo pero puede servir para intensificar la conciencia (García de Blas, 25-7-2011; Go!, 2015: 31). La poesía no es en sí misma un medio, un instrumento, una plataforma, sino un lenguaje, un modo de organizar el pensamiento, de cultivar el mañana. En cierta manera, el binomio grafiti-poesía asegura que la sociedad tenga a mano una conciencia crítica y una coraza emocional contra todas las formas de muerte.

\section{Neorrabioso: pintada de autor}

Cuando nos referimos al desarrollo del grafiti poético como tipología histórica en nuestra cultura, como sucede con las firmas grafiteadas o los grafitis artísticos, desde la caricatura hasta el caligrama, vemos una sucesión de variaciones o revisiones que desembocan en su versión o sus versiones contemporáneas. En el caso del grafiti de leyenda podemos afirmar que aparece lo que podría bautizarse como pintada de autor (Figueroa, 2014: 277-306), fundamentalmente derivada de factores tales como la acción perseverante, la continuidad gráfica-conceptual y la expresión de la autoría individual o colectiva. Situación que puede hacernos evaluar qué factores ideológicos y culturales subyacen tanto detrás del tagging, el Writing o el Graffiti, como del fondo de toda la panoplia de

\footnotetext{
${ }^{15}$ Existen iniciativas bajo el mismo nombre, pero que, aunque pudieron estar inspiradas en el proyecto de Armando Alanis Pulido, tomaron su propio camino. Por ejemplo, desde La Casa del Barrio de Carabanchel se realizan esporádicamente, desde el año 2014, «acciones poéticas» consistentes en sembrar diferentes calles del barrio con poemas fotocopiados o escritos a mano sobre papel, que los participantes han seleccionado previamente, entremezclado y repartido entre ellos para pegarlos en muros o mobiliario urbano [https://www.facebook.com/pages/Acción-Poética-Carabanchel/ 178690132314755, última consulta 21-6-2016].

Otra iniciativa, impulsada entre otros por el poeta Luis Santos, más acorde con el criterio de Alanis Pulido es la realizada desde 2014 por la Acción Poética de Colmenar de Arroyo (Madrid) y que involucra a vecinos del pueblo en la recogida de versos y en su escritura mural. Como añadido le suman la realización de objetos poéticos para su venta benéfica, destinada a una ONG [https://www.facebook.com/accionpoeticacolmenardelarroyo, última consulta 21-6-2016]. Los criterios que rigen en la selección de los versos se resumen en que sean frases respetuosas, arreligiosas y apolíticas, no cursis, positivas, originales y creativas (aunque pueden ser de otros, siendo citados), sugerentes y un poco burlonas, sintéticas (menos de diez palabras); lo que deja a ciertos géneros fuera y destaca el carácter filantrópico y sanador de la poesía.
} 
propuestas del Street Art o de esas mismas pintadas poéticas, firmadas por un grupo o un individuo, que parecen forjar las nuevas corrientes grafiteras.

Las frases de Neorrabioso se definen en principio como versos, poemas de un único verso, y que pueden considerarse al mismo tiempo sentencias, aforismos descreídos, axiomas radicales, adagios trastocados, proverbios cariñosos, neorrefranes espasmódicos, etc., expresiones de una experiencia que antepone el tamiz de las emociones y la creatividad al frío contacto con una realidad deshumanizada. Por eso, parece más oportuno ligar las pintadas de Neorrabioso a lo que sería una greguería, una greguería urbana, pues el sentido del humor reluce mucho en sus versos gracias, antes que al informalismo o gamberrismo del medio, a la exaltación del juego de palabras o la metáfora que, si destacan por algo, es por manifestar que su origen proviene de un autor con dotes de agudeza mental y originalidad imaginativa. Neorrabioso, Batania de Lauros, sería un filósofo de calle, a medio camino entre un Epicuro y un Diógenes.

Batania (Alberto Basterretxea Martínez) nació en 1974 en Lauros (Vizcaya) y estudió periodismo. Con veinte o veintiún años empezó a escribir poesía por amor, pero la determinación de ser poeta surgió por un penoso detonante: la muerte de su padre en enero de 2004. «Yo no soy un escritor por vocación, escribo desde que murió mi padre, si me lo devuelven dejo de escribir», declararía (García de Blas, 2011) ${ }^{16}$. En octubre de 2007 se radicó en Madrid, donde aún reside y donde ha realizado, en este tiempo, más de quinientas pintadas. Su decisión de trasladarse a la capital entrañaba una huida de la tormenta, la ruptura con una amargura agravada por la obsesión, el dolor, el aislamiento y la crueldad, y, a la vez, la confrontación directa con el corazón de los dramas que, en él, se representa como un conflicto situado entre el compromiso político y la necesidad personal de «aniquilar su pasado» (Acción Fílmica, 2014; Batania, 2014: 251-256, 326) ${ }^{17}$. En consecuencia, realizar estas pintadas en la capital del estado adquiere un fuerte simbolismo, ya que es ubicar físicamente su pensamiento crítico a uno de los epicentros de las preocupaciones dialécticas de su

\footnotetext{
${ }^{16}$ Toda poesía y, por tanto, toda pintada de autor gira en torno a unos temas recurrentes, según los gustos, inquietudes y motores de sus autores. La obra de Batania tiene por ejes: Iratxe-Natalia, su padre y la poesía social, lo que se resume en poemas de amor y poemas políticos (Acción Fílmica, 2014). Batania reconoce que sus primeras pintadas sociales son una emanación del pensamiento de su padre. Por eso, no tiene empacho en declararse plagiador de su padre y que éste crece cada vez más dentro de él, un modo de reconocer su dependencia o peso en la construcción de su persona. En gran parte, se presta a la dinámica del duelo, a seguir dando voz al ausente, a negar su muerte («La muerte me queda demasiado grande»), una reordenación interior que conjuga la sed de justicia, el inconformismo, la rabia social, etc. (Acción Fílmica, 2014). Así, convierte a su padre en un tema político, en lo que parece una forma de sobrevivirlo. Sin embargo, su nombre nunca se cita en el muro, fundida su identidad en el alter ego de Neorrabioso.

${ }^{17}$ Siguiendo a Robert Ezra Park (1952), la ciudad se convierte en una fuerza capaz de formar y liberar a la naturaleza humana de una manera nueva -incidiendo este caso particular en la visión de la urbe como un liberador de las presiones del mundo rural- Estima que en cualquier sociedad el individuo lucha por preservar su respeto a sí mismo y su punto de vista, pero sólo puede lograrlo ganándose el reconocimiento de otros (Fernández Álvarez, 1994: 248-249). Esto es patente en el impulso de Batania, pero igualmente, lo es que la misma ciudad, con su orden social, sus hábitos de vida y creación de necesidades, dificulta lograr ese orden moral, perpetuando una situación de conflicto, al menos fuera de los mundos autocontenidos o regiones morales que asociamos frecuentemente con la delincuencia, el lumpen o el underground (Cressey, 1969: 31; Park, 1952: 50-51; Hannerz, 1986: 36-37), pero que podemos ampliar a los reductos subculturales o las burbujas personales. En este caso, el arte sirve como medio para superar el estado caótico, desordenado e insoportable en que el mundo se encuentra, o así se percibe, para un temperamento insatisfecho e inquieto (Hauser, 1973: 152), aunque entre los artistas ácratas el caos sea naturalidad e indicio de libertad, sumándose a las fuerzas, desde los patrones oficiales, caotizantes, en lo que no deja de ser un reordenamiento alternativo.
} 
padre y que él hace suyas, de tal forma que puede considerarse un performance dilatado en el tiempo, un discurso.

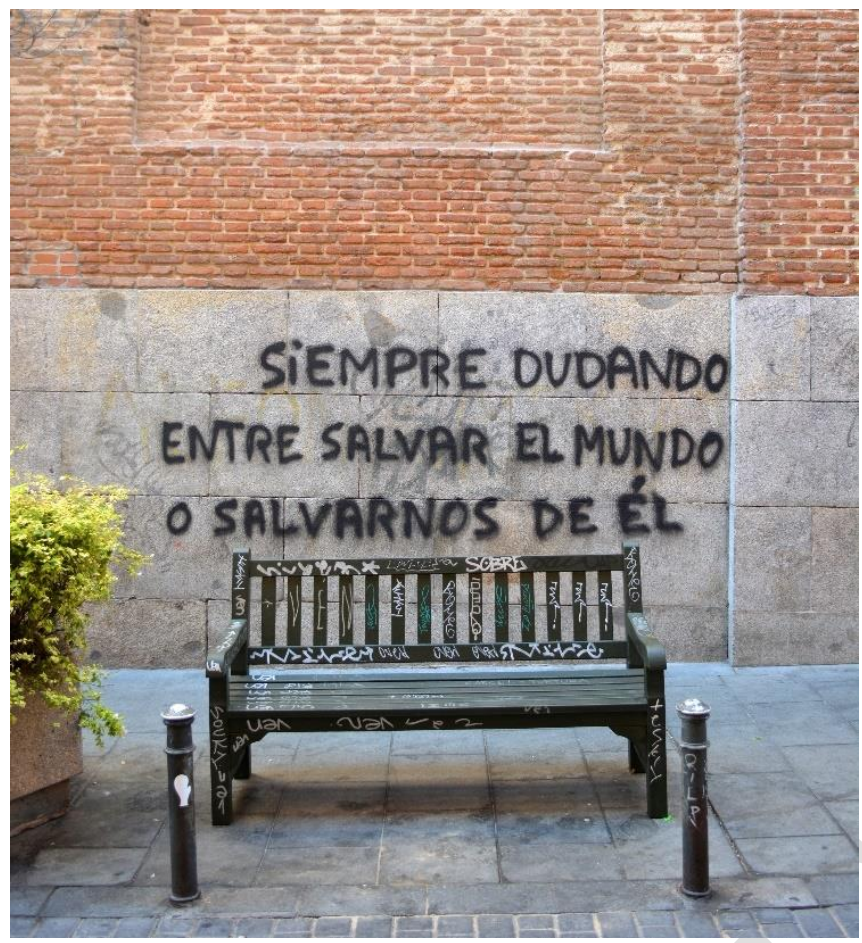

Fig. 1. Batania Neorrabioso. Agosto de 2013. Fotografía de Guillermo de la Madrid, www.pintadoenlapared.com.
Performance que tiene también una importante faceta terapéutica ${ }^{18}$. En sí el grafiti se presta a ejercer el papel de representar, a modo de metáfora, tanto el conflicto social como su conflicto interior. No es de extrañar, pues algunos notables artistas urbanos han contado entre los desencadenantes de su actividad mural un trauma vital, incluida la muerte de algún ser querido. Esa mortificación, no obstante, implica o conjura un renacimiento que Batania resumió con una pintada paradójica: «Al fin he ascendido hasta el cero», con la que representa el descenso, el vaciado necesario para reemprender el vuelo y la liberación del peso del dolor. La pintada se muestra, pues, como síntoma y medicina. Así mismo, Batania alude a ese aspecto terapéutico y amoroso de su actividad en términos que apelan al fortalecimiento de la autoestima, para conjurar

impulsos de autocastigo o autodestrucción, y la conciencia de la transitoriedad de posibles fases de melancolía, misantropía, paranoia o megalomanía (Go!, 2015: 31). Un periodista le preguntó sobre si el miedo a la muerte fomentaba la creatividad, a tenor de la idea de que el artista perdura vivo en su obra. La respuesta de Batania fue clara: lo que la fomenta es «el desamparo, el resentimiento, el afán de venganza y todo tipo de carencia, sin negar que se puedan escribir poemas buenos desde la salud y la alegría [...] el poema está en la herida y [...] cuando te duele algo, se escribe mejor» (Go!, 2015: $31)$.

El nombre de Batania surgió de donde nace la tierra de un apátrida: su cuerpo. Por tanto, Batania es un manifiesto vital y político:

Batania no responde a motivos eufónicos ni literarios sino a motivos políticos y existenciales: si me hubiera llamado Ricardo Neftalí Reyes o Lucila Godoy nunca lo habría sustituido por Pablo Neruda o Gabriela Mistral. Pero ocurre que el pasado trabajó en contra y cargó mi nombre y apellidos de connotaciones políticas, ideológicas y territoriales que yo juzgo malsanas, de forma que, al morir mi padre y producirse en mi interior el gran estallido, decidí desprenderme de ellas: de ahí el sueño de escribir. Escribir en político, se entiende, escribir alejándome y denunciando lo falso adquirido, lo sectario heredado, lo nuestro que no es

\footnotetext{
${ }^{18}$ Miembros veteranos del Graffiti autóctono como Juan Manuel, Muelle o Bleck (la rata) resaltaban ese aspecto creativo performativo, que redundaba en la consideración de su actividad como una terapia colectiva que oxigenaba la vetustez urbana, reconociendo su dimensión artística o poética, dentro del contexto de una lírica urbana, de la consideración del espacio público como un espacio para el buen rollo y la alegría de vivir (Gálvez y Figueroa, 2014: caps. 10, 11). Esta visión se diluiría con la progresiva constitución de una comunidad masificada de escritores de graffiti, produciendo un variopinto enfoque acerca del civismo alternativo o la asocialidad nihilista del Graffiti.
} 
nuestro. Batania es una propuesta de espacio personal, un contrapaís de 1 ` 76 de altura y 67 kilos de peso situado entre Argüelles y Malasaña, con un PIB mensual de 856 euros que se invierte a medias en alimentos para el estómago y el cerebro. Proviene del mestizaje de latania, palabra que leí por primera vez en Ocnos, de Cernuda, con el episodio de los batanes de El Quijote (Uranga, 2012).

¿Qué es Batania? «Batania es mi concepción del espacio. Yo soy mi propio país. Y mi país tiene 1,74 metros de altura, 70 kilos de peso, 815 de PIB mensual». El autor sacó este otro nombre del libro Ocnos de Cernuda y del episodio de los batanes de El Quijote, cuando «don Quijote se asusta pensando que son unos gigantes y resulta ser una máquina de batanes. Soy un batán, un tipo que grita mucho, pero luego soy superpacífico» (Hernández, 2013).

Neorrabioso sería el alter ego callejero de este poeta ${ }^{19}$, el locutor que suscribe sus pintadas, un pseudónimo o máscara con toda una potente carga contracultural en un tiempo de confusión, en el que estar contra la cultura, al igual que estar contra el sistema, puede suponer paradójicamente estar a favor de los principios que pretende alcanzar y declara defender ese sistema o esa cultura, y que se propagan desde retóricas como la publicidad o la educación escolar. No obstante, la elección de ese nombre fue un acto de ironía:

Neorrabioso es la propuesta de tiempo de Batania, un tiempo de rompan filas. Cuando comencé en la poesía se me hizo la misma crítica desde muchos ángulos: mis poemas, decían, eran tan violentos que no se entendían en una democracia. «Escribes demasiado rabioso», me precisaron, y yo me añadí el neo- más por autoparodia que por intención agresiva. El adjetivo me vino a la cabeza por una carta de Clarín a Menéndez Pelayo que leí por primera vez en Los ensayos liberales, de Gregorio Marañón.

Por otra parte, que el nombre de Batania sea femenino no es casual sino premeditado: si escribo es gracias a la tensión que se establece entre las tres aes del espacio Batania y las tres oes del tiempo neorrabioso. Me referí una vez al artista como andrógino y sostuve que el poeta ideal tenía su parte de poeta y su parte de poetatriz. Hasta hice una pintada diciéndolo: «Neorrabioso: porque soy macho. Batania: porque soy hembra» (García de Blas, 2011; Uranga, 2012; Acción Fílmica, 2014).

En consecuencia, el empleo de Neorrabioso por Batania para firmar sus pintadas resalta más aún ese tono lúdico y divertido que quiere imprimir a su obra, para despojarla del dogmatismo típico de la académica retórica poética o la grandilocuente retórica política, pauta heredera del grafiti del Mayo francés (Kozac, 2004: 48-49), además del recurso de la poesía (Kozak, 2004: 53-56) ${ }^{20}$. Se liga así a esa forma de atacar la alienación en el marco cotidiano con nuevas estrategias de combate, no precisamente agresivas, y negando que el arte, la poesía, se pondere como una mercancía. Subraya, con vigor, la vitalidad humana frente a la épica arenga política, o bien rebaja el empaque sacro de la creación artística hacia lo mundano, realizando una poesía de proximidad.

\footnotetext{
${ }^{19}$ En concreto, Batania considera a Neorrabioso como una actitud, un «tiempo personal» dentro de su vida de poeta (TeleK, 2012). Como podemos apreciar en la etimología del nombre de Batania, tanto Batania como Neorrabioso constituyen sinónimos de un mismo cuerpo, un poliedro con varias caras.

${ }^{20}$ Aún está por ver en qué medida las frases de Neorrabioso arraigarán en el imaginario colectivo y se fijarán como memes o tópicos grafiteros. Su parentesco con toda esa serie de juegos lingüísticos del situacionismo sesentaiochista, encaminados a generar una visión crítica y un cambio de la forma de vida y que calaron más allá del Mayo del 68, lo avalaría.

Un bloque propio es todo lo que atañe al mundo sentimental y a la poesía, que incluso implica una sublimación universal de episodios autobiográficos, en los que aparecen implícitamente las figuras de Iratxe y de Natalia, o como autoras de las frases dirigidas a sí mismo. En varias ocasiones estas pintadas son también títulos o versos de poemas, como los aparecidos en su obra El amor es un ave sin nido que pone huevos en el aire. Poemas de amor y destrucción (2013). Las alusiones a la poesía se unen con las alusiones a las pintadas, en una dimensión autorreflexiva que admite en último extremo la necesidad de la acción frente a la contemplación: «Basta ya de pintadas pasemos a los besos».
} 
Firma sus pintadas como Neorrabioso, escrito en minúsculas y rubricado con una línea que subraya el nombre. En ocasiones firma con otros nombres (Iratxe, Natalia), pero reproduciendo en esas firmas los mismos estilemas gráficos de su firma. Esto se debe a su sentido de la propiedad intelectual, reconociendo libremente la autoría original de esas frases o poniéndolas en boca de quienes las inspiraron o pronunciaron. También puede añadir a su firma, cuando suscribe reinterpretaciones de citas de otros autores, los nombres de éstos, convirtiéndolos en coautores de la pintada ${ }^{21}$. Rara vez no firma, pero desconozco si eso se debe a una posible alarma-huida o lapsus. En todo caso la caligrafía y el estilo literario, gracias a la difusión de su obra, bastan para fijar la autoría, que se conforma en una marca de fábrica.

En este punto, conviene detenerse en el valor de la caligrafía como caracterizador o anclaje de la interpretación. En aspecto, sus pintadas recogen rasgos ya vistos en otros precedentes: el uso de una caligrafía de corte tipográfico, pero de clara factura manual, compartida por algunos de los autores anónimos del Mayo del 68 o con Acción Poética. Como pasaba en el caso de los versos del Dr. Hofmann o en el de las

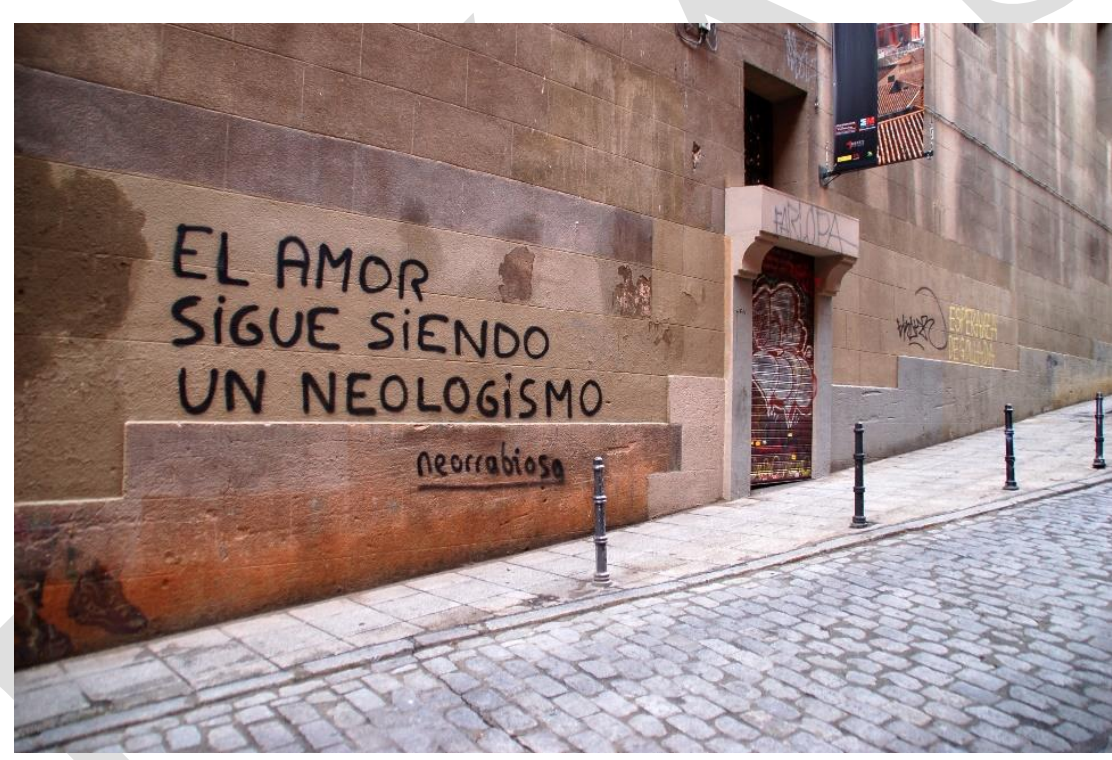

Fig. 2. Batania Neorrabioso. Noviembre de 2012. Fotografía de Guillermo de la Madrid, www.pintadoenlapared.com.

grafiteadas de Mujeres Creando, ya sólo el uso de una escritura manual, en estos cursiva o cuidada, nos remite a la dimensión emocional de la escritura y, por tanto, a la idea preestablecida de su personalización e inmersión cómplice en la intimidad de un escritor que abre su interior a los demás, rehuyendo la resonancia de una reproducción mecánica e impersonal. En cierta medida, reivindica el aura del texto como dimanación de un ser, exponente de una personalidad, trazado de un cúmulo de experiencias, y revalora lo especial de una vivencia compartida. En cambio, Batania con sus letras capitales parece fortalecer la atención sobre la idea, antes que sobre el autor. Planteamiento evidente en cuanto disocia la caligrafía y tamaño del verso de las de su firma.

Poder desarrollar su vocación poética de un modo coherente a su credo obliga a Batania a optar por la autonomía económica (Go!, 2015: 31). Eso requiere tener un empleo no absorbente y compatible con la creación artística, que le libere de la presión comercial y le permita crear productos de calidad.

\footnotetext{
21 Por ejemplo, «Lo peor es cuando terminas la pintada y la pared no aplaude» [firma doble, como: O. WELLES / neorrabioso], pues es una reinterpretación de una cita atribuida a Orson Welles: «The worst is when you've finished a chapter and the typewriter does not applaud».
} 
Por tanto, renuncia a pasar por la prueba de convertir su arte en mercancía: «Para algo que hay en mi vida bonito, no quiero mancharlo con dinero» (García de Blas, 2011). En este sentido, Batania articula una particular autarquía, en la que tiene cabida la autoedición o el regalo de cuadernillos y camisetas, y aspira a una ataraxia o paz interior como meta personal, para lo que prima conseguir lectores antes que consumidores-compradores ${ }^{22}$. Junto a esto, vertebró su actividad en torno a una triada mediática, que le aleja del mainstream y le circunscribe al underground: blog-pared-bar (Acción Fílmica, 2014) ${ }^{23}$. Cada uno de estos medios, alternativos por cuanto no son controlados o dirigidos por el poder oficial o el interés económico, tendría sus propias peculiaridades, siendo común en todos su distanciamiento de la alta cultura y el consumo de masas. El más próximo al receptor es sin duda el bar, donde recitales y tertulias permiten un contacto directo entre creadores y amantes de la poesía ${ }^{24}$, pese a que su repercusión es bastante endógena. El grafiti, en cambio, es el más expuesto y representa la exaltación de su juglaría, del verso libre y con sentido en toda su dimensión, cercano al habla popular, pero con giros conceptuales que sorprendan y despierten el seso. Oficio con irreverencia, fe con albedrío, una actitud o filosofía que conecta, salvando la distancia, la poesía goliardesca con la música rock, el deambular de los cínicos con la deriva postmoderna.

El 25 de agosto de 2008 inicia su actividad mural con torpeza y valentía. Conviene resaltarlo, pues, aunque se afirma que empezó a grafitear a raíz de la eclosión del 15-M, en el que participó (García de Blas, 2011), ese hito sólo pudo suponer una intensificación, en la que posiblemente intervino el establecimiento de una nueva relación sentimental (Natalia). Igualmente, su inmersión en la pintada de autor ha de entenderse como fruto de la extensión de su política de autor (Veoguadatv, $2011)^{25}$. El recuerdo de su paso al muro resuena con la fascinación de un ritual de iniciación. Así lo narra (Batania, 2014: 84):

Serían las tres de la madrugada cuando me vinieron los deseos de correr: yo solo quiero eso, me basta con ser un segundo más joven que ellos. Había comprado tres aerosoles Pinty Plus de color negro mate en una tienda de chinos, dos euros cada uno, y me fui a la calle Los Pajaritos, donde había visto una pared a la

\footnotetext{
${ }^{22}$ El primer libro publicado por Batania fue con una editorial, La Baragaña. Hecho que se produjo, pese a la reticencia, por dar mayor eco a su poesía fuera de Madrid y no tanto por afán de lucro. El contrato permitía a Batania mantener los contenidos del libro en su blog, de acceso libre y gratuito (Uranga, 2012).

${ }^{23}$ Batania rechaza la etiqueta de underground (Acción Fílmica, 2014), por la simple razón de ser originario de un entorno rural. No obstante, considero que se mueve en esas coordenadas, más por imperativo cultural que por elección personal, empujado a ubicarse en esas coordenadas como movimiento táctico y encasillamiento social. Su ubicación no responde en verdad a un malditismo, a pesar de que, como reconoce, la elección de llegar a ser poeta supone perder dinero y salud, tal y como funciona este sistema sociopolítico.

${ }^{24}$ Batania destaca sobre todo dos lugares en el barrio de Malasaña: el Bukowski Club y el Diablos Azules, al que se sumarían otros puntos con más solera como Libertad 8, en Chueca. Respecto al blog, éste tiene gran eco en Madrid, México DF, Buenos Aires y Miami, por ese orden (Uranga, 2012).

${ }^{25}$ Batania se distancia de un arte militante plegado al dictamen de un cuerpo doctrinal, incluso en materia estética, propio de la deriva totalitaria de las ideologías. Punto importante por cuanto se hace patente que su pulsión creativa alimenta un ideario libertario en el que se resalta el coherente papel del grafiti, tal cual, como idónea plataforma de exhibición libre en los márgenes culturales, subrayándose a todo esto la entidad del barrio como comunidad humana y la calle como foro de intercambio cultural y, en definitiva, espacio político. En su persona conviven el poeta y el ácrata, sin poderse discernir si verdaderamente desde los parámetros del siglo XX y XXI ambas entidades pueden separarse cuando coexisten bajo la premisa de la consagración a la libertad y la épica humildad del autor enmascarado. A este respecto, la liberación de la poesía y su desparrame ahonda en la idea de la democratización del arte y su salida de espacios-reducto o ámbitos especializados que no hacen más que conducir a la cultura a un estado mortecino.
} 
que caía bien (pero no: no es cierto que me guiñara un ojo). Mientras le hacía esta pintada, No quieres hacer la vida que te toca, no paré de mirar histérico a todos los lados, pues solo empecé a disfrutar del miedo veinte grafitos más tarde, y con los nervios ni siquiera advertí que había escrito la Q sin el rabito, igual que la $\mathrm{O}$, y parece que digo "ouieres" en vez de "quieres". Era la primera de mis 491 pintadas, fea como todas y grande como siempre, como pensada para personas con la prueba del oculista sin superar. Recuerdo que volvía a casa muy contento, como si hubiera matado un cíclope o hubiera rendido Cartago. Ya he dicho que solo quiero correr: yo solo pararé cuando vea a mi padre. Era el 25 de agosto de $2008 .^{26}$

Resulta evidente que, como sucedió con otras irrupciones sorpresivas de pintadas, su impacto inicial se basase en la gracia de su texto y el misterio de su autoría, y fuese ese mismo misterio lo que generase un mayor interés por desentrañar su significado. La perseverancia del autor influye en una normalización de la percepción de su obra dentro del tejido urbano, cuya mayor prueba es la consolidación de una comunidad de seguidores. En el caso de Batania es evidente, sobre una escena en la que ya de por sí hay un gran interés por todo lo que suceda en el espacio urbano, habiendo una comunidad propia de recopiladores o documentalistas de grafiti o arte urbano. No obstante, mientras llega esa fase, el autor asume un estadio inicial de «llanero solitario».

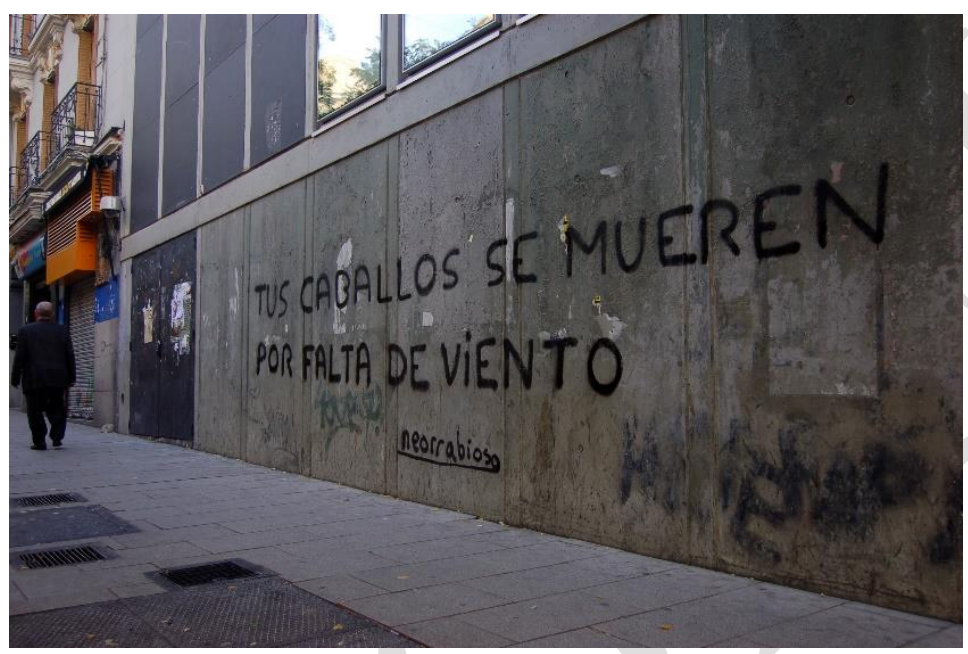

Fig. 3. Batania Neorrabioso. Noviembre de 2010. Fotografía de Guillermo de la Madrid, www.pintadoenlapared.com.

En gran medida, el estado del grafitero como solitario corredor de fondo se congracia con el requisito de recogimiento para la producción poética, a pesar de que el concepto de poeta globetrotter que esgrime Batania nos recuerde el carácter callejero, todoterreno y espectacular del artista postmoderno ${ }^{27}$. Digamos que, aunque se requiere un aislamiento operativo tanto en la fase de concepción como en la de ejecución, se atempera la impresión de soledad espacial y social tan pronto se entiende que, en la jungla de asfalto, además de uno hay otra fauna y flora, activa o pasiva, pululando junto a sus muros, entre las altas azoteas y los espacios suburbanos. Ese monólogo asume y aspira a verse quebrado en algún momento, a diferencia del trabajo en un lugar íntimo, al sugerirse como diálogo mediante su exhibición pública, y es entonces, con la conciencia de ser oído, comentado y de convivir, cuando el autor confirma la existencia de prójimos, en el caso de seguidores, o de semejantes, en el caso de otros

\footnotetext{
${ }^{26}$ Este testimonio resalta la sensación de miedo provocada por una situación fronteriza, y nos advierte del notable peso como leitmotiv en algunas de sus pintadas («Siempre cambiando el miedo de sitio», «El punto medio es el punto miedo», «El miedo dio a luz: ha tenido trillizos»). No obstante, para él es un miedo activador, no bloqueador, del que se enorgullece y del que se desprende el entusiasmo por emprender la aventura de superarse (Batania Neorrabioso, 2014: 254).

${ }^{27}$ No puede obviarse el carácter de «aventurero urbano» de Batania, protagonista de una «épica del desencanto» que le lleva a configurarse como un «encantador del hormigón» y «libertador cívico». Desde el plano artístico, el arte (léase la poesía grafiteada, pero también otras tipologías grafiteras) constituye un medio para apoderarse del mundo por la violencia o por el amor (Hauser, 1973: 152), idóneo e inevitable en una sociedad cuyo espacio público está hiperregulado y controlado, y cuyo grafiti bascula entre ambas orillas; siendo Batania un explorador de lo humano y un domador de su salvajismo civilizado.
} 
poetas urbanos ${ }^{28}$; incluso asiste a la representación simbólica, psicodramatizada, de su conflicto comunicativo en los muros o en su blog, o como él lo llama: su blog-maquinaria ${ }^{29}$.

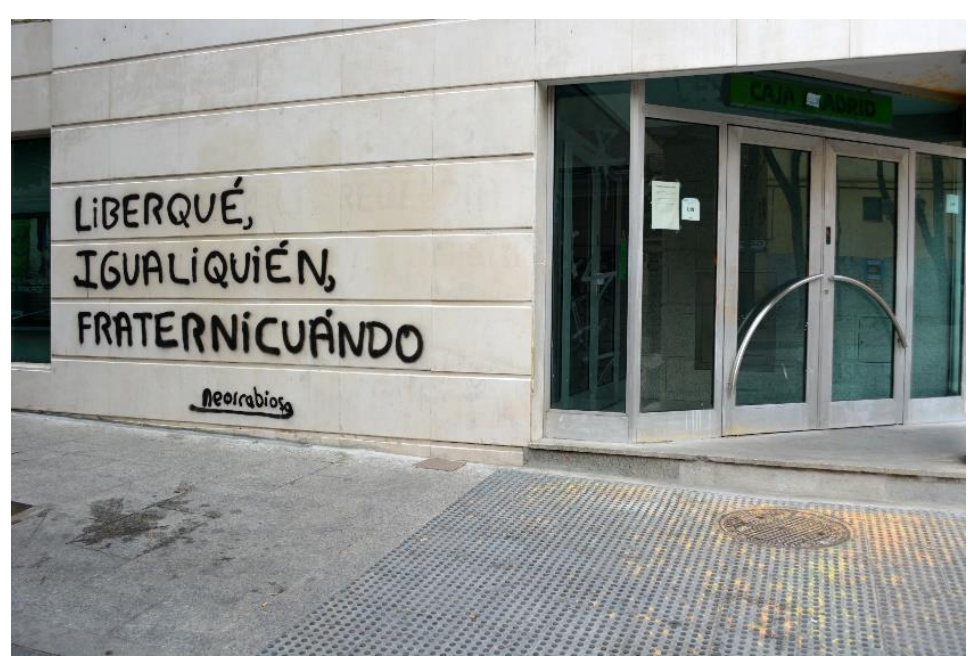

Fig. 4. Batania Neorrabioso. Febrero de 2013. Fotografía de Guillermo de la Madrid, www.pintadoenlapared.com.

Ésta es una diferencia notable con las producciones realizadas en los años sesenta, setenta y ochenta, pues desde los noventa se ha considerado y aceptado lo imperativo del destino mediático de estas producciones públicas, su exhibición virtual. Aún más, se ha concebido el diseño de «sitios oficiales», webs destinadas a la opinión pública y al público específico que sigue determinadas actividades culturales, minoritarias o reservadas. Ese blog-maquinaria supone, por tanto, una herramienta del autor para observar y evaluar, casi a modo de experimento sociológico, las repercusiones de sus actos, así como establecer un diálogo público y exponer otros materiales típicos de un blog literario (artículos, reseñas, entrevistas...). Por otro lado, suma el lanzamiento de versos en formato de cartela en su Facebook ${ }^{30}$, compartiendo otras reflexiones sobre el mundo que le rodea, sin que falten lo poético, y una cuenta de Twitter $^{31}$, ajustándose fácilmente sus versos al formato de tweet (Batania, 2014: 319-328) y, al igual que hacen otros escritores, afianzando el vínculo con sus seguidores por medio del microblogging. Se trata de una dinámica de época, ocasionada por la adaptación del mundo literario y editorial a las nuevas plataformas de comunicación, y que propaga los pequeños formatos para facilitar el consumo cultural. Posiblemente el éxito del tweet se precede por el éxito de la pintada, ya que comparten la misma concisión o minimalismo (Gándara, 2002: 39). Aunque Batania se distancia de producir una fast food literaria (haiku vs. slogan) y se alinea entre quienes desean generar versos de calidad: «La poesía, tanto para el autor como para el lector, exige una calma que contraría la aceleración consumista, la satisfacción inmediata» (Go!, 2015: 31). Esto es vital por cuanto se refleja en un proceso de creación o concepción «sosegado». A menudo las pintadas son versos de sus poemas. Incluso, versos que se resisten a morir tras el desahucio de malos poemas, fruto de la selección de frases surgidas en sesiones

\footnotetext{
${ }^{28}$ El grafiti simboliza, como casi toda la producción artística en el espacio público, un donarse, un darse al otro, independientemente de las contrapartidas. Sin embargo, el carácter vulgar o infame del grafiti favorece curiosamente la interacción sincera, la respuesta sin complejos. Cuestión muy querida para alguien que aspira a la activación del espectador y de ahí la necesaria renuncia a una comunicación unidireccional, reflejable sobre el muro a modo de réplicas, cómplices o críticas. No se trata de arengar o adoctrinar mediante eslóganes o lemas, se trata de transmitir y hacer sentir, pensar, avivar el seso y el corazón del viandante-lector hasta el punto de hacerle expresarse y completar así la propuesta de diálogo. ${ }^{29}$ [http://neorrabioso.blogspot.com.es, última consulta 21-6-2016].

30 [https://www.facebook.com/pages/Batania-Neorrabioso/187580034398, última consulta 21-6-2016].

${ }^{31}$ [http://twitter.com/neorrabioso9, última consulta 21-6-2016].
} 
de escritura automática y que él finalmente convertirá en escritura popular (Acción Fílmica, 2014). Del mismo modo, la acción mural no es un «aquí te pillo, aquí te mato», sino que está precedida por un conocimiento del medio, una observación detenida del entorno y una selección adecuada del soporte $^{32}$. El furtivismo no entraña precipitación ni la no solicitud de permiso excluye la planificación, si lo que se pretende es hacer una pintada de calidad.

Finalmente, he de señalar que Batania entiende que Internet ha facilitado la deselitización del «consumo» poético, favoreciendo su simplificación y divulgación y generando un nuevo tipo de poeta, cibernauta y bloguero: el poenauta, asentado en una imagen virtual que con suerte coincide con su imagen real (Batania, 2014: 94). Para él, «la poesía se había vuelto minoritaria por los temas que trataba y los modos en que los desarrollaba» (Go!, 2015: 31), siendo algo fundamental en su apertura el derribo de una arquitectura de control (editoriales, ateneos, premios, suplementos literarios...) mediante la creación de una marabunta de blogs, de mayor, menor o ínfima calidad. Un mal menor frente al universo de posibilidades de libertad creativa y trato directo autor-lector que Internet ofrece a un mundo que adolece de serias limitaciones, que se resumen en dos factores: falta de lectores y endogamia.

Es por esa razón por lo que Batania, desde una iconoclastia lírica, se sirve de las nuevas plataformas para derribar muros, jugar con las convenciones, las palabras y los conceptos, y romper esas barreras invisibles que entorpecen la autorrealización personal y la construcción comunitaria, el intercambio real de ideas o impresiones, y el diálogo y la comunión humanas. Consiguientemente, a su juicio, la poesía tiene ahora una oportunidad, como le sucede a otros ámbitos culturales relegados, gracias a la eclosión de Internet. Pero no ha de entenderse esa bonanza ganada en términos de calidad productiva, sino de efervescencia creativa o recreativa, como si esa calidad tuviese que devenir en un futuro, de modo natural, tras esta etapa de reapertura pública.

En sí, las herramientas digitales se han sumado a una pauta descrita por Frank Popper en el arte contemporáneo de postvanguardia, citando a Mikel Dufrenne (1974), por lo que surge un arte que opera una revolución formal en su «ámbito», pero que también sale de su gueto, transgrede su concepto y rehúsa su institucionalización, o sea, «una práctica utópica y alegre que trastorna la producción y el

\footnotetext{
${ }^{32} \mathrm{Al}$ igual que en otros ámbitos grafiteros, Batania selecciona el muro según criterios éticos. El poeta busca pretiles, tapias, muros vistosos, sin ser fachadas principales de vivienda o pequeño comercio. Si pertenecen a bancos y grandes corporaciones, o a edificios públicos (no monumentos), son óptimos, pero adecuando el contenido del grafiti al significado del soporte. Ese sentido del decoro temático, ajustando el mensaje al lugar o completando o anclando su significado gracias a su ubicación, incide en un rasgo peculiar de los que se constituyen como focos de atracción grafitera: hitos del paisaje que fomentan el ejercicio grafitero por prestancia, tradición o coyuntura.

Batania, en todo caso, no renuncia a su responsabilidad, pero, sin duda, su descarga de culpa social se forja mediante la evaluación positiva del bien que se ejerce con estas acciones sin necesidad del aval burocrático de una institución pública. Antes que un outlaw ethos (Brewer, 1992: 194) o una región moral (Park, 1952: 50-51), podríamos hablar de un criterio alternativo, ya que su reafirmación no proviene de una comunidad cerrada, sino del reconocimiento público, o de parte de la ciudadanía, a pesar de la marginalidad de la que parte su propuesta.

Su obra se distribuye por áreas en las que ya hay una propensión por grafitear: Vallecas, Portazgo, Nueva Numancia, Puente de Vallecas, Pacífico, Atocha, Príncipe Pío, Lavapiés, Malasaña, Noviciado o Argüelles; y que, de un modo u otro, le son familiares al formar parte de su tránsito cotidiano.
} 
consumo regulados por la ideología» (Popper, 1989: 262). El nuevo arte popular, tal y como germina en los años sesenta, está profundamente ligado con lo social, pero no se confunde con él, remarca sus límites estéticos, como también se enfrenta contra ese arte popularizado o mediatizado, que sirve para dar gusto, entretener y uniformar las expectativas de la población.

Esto nos lleva de nuevo al grafiti, y a tomar mayor conciencia de las implicaciones y motivaciones concretas que impulsan a un autor a trasladar su actividad poética a las calles y cómo esta faceta adquiere un peso central y se convierte en una piedra clave sobre la que se realza su actividad creativa y se asienta su eco mediático ${ }^{33}$. Así lo expresa Batania:

Ni los libros ni los bares ni las pantallas interneteras llevan la poesía a la gente, [...] lo que sucede realmente es que todo el mundo hace versos para gente que hace versos y ahora, socializadas las nuevas pistas de aterrizaje, desde el más poetísimo al poeta más cariado puede llegar a los otros poetas, fijaos bien en lo que digo, los poetas forman tal plaga de langostas que hacen la ilusión de público pero no hay tales carneros, seguimos sin llegar al ciudadano, la palabra gente sigue siendo un megaterio. [...] Llegado a este punto quise hacerme las preguntas definitivas. ¿Existe una manera de llegar con poesía a la gente que no acude a la poesía, que es casi todo el mundo? ¿Se puede llegar a Jaime el del cuarto, a Rafaela la del ático, al carnicero y a la abogada, incluso a los gatos y a los mirlos, aunque para ello no deba convocarles sino acudir hacia ellos, no citándoles sino saliéndoles al paso, casi agrediéndoles? Puestos en esta tesitura pensé, ya con el colmillo alegre, ¿existe una modalidad de poesía donde cada error del poeta merezca un castigo, una modalidad que evite el blablabeo / logorrea versimotora y se recuperen las ventajas y desventajas de la censura? ¿Donde cada acierto no signifique nada y cada fallo 3000 euros de multa de la policía? Y ya en el colmo de la masturbación: ¿sería posible que a la sola vista de mis versos la gente no solo aprobara sino dijera algo más fuerte, un «ESTE TÍO ES EL PUTO AMO» o, puestos a desaprobarlos, no se quedara en una mera negación sino en algo más agresivo, un «QUÉ HIJODEPUTA EL QUE HA ESCRITO ESTO, QUE PINTE EN SU PUTA CASA»? (Batania, 2014: 83-84).

Sin duda, alcanzar un público ajeno es una aspiración importante en cualquier faceta cultural, incluida la underground. Toda tipología grafitera tiene unos criterios de selección del público, pero estos pueden ser más o menos abiertos, siendo las vertientes crípticas las más cerradas. Aunque en este caso exista un tamiz cultural, las pintadas en general no se convierten en algo selecto y exclusivo en los mismos términos que las producciones de la alta cultura, más bien pueden ser algo selectivo y excluyente en

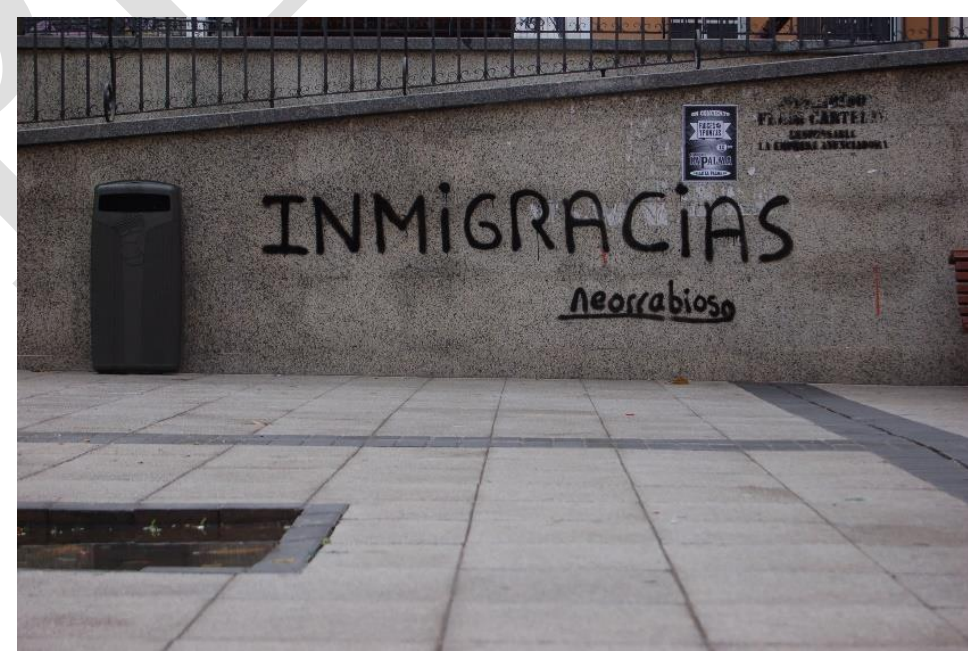

Fig. 5. Batania Neorrabioso. Noviembre de 2010. Fotografía de Guillermo de la Madrid, www.pintadoenlapared.com. ciertos casos, dentro de su aparente accesibilidad general. Sin embargo, al igual que algunos escritores de graffiti se plantean llegar al público general, Batania no se dirige a los poetas, sino a la gente.

\footnotetext{
${ }^{33}$ Batania es sensible al contrapoder de los mass media y el papel protector del grafiti para su integridad. Los periodistas que se interesan por él no prestan la atención deseada sobre los temas que trata en su obra, lo que a todas luces es un fracaso. Batania achaca esto a la banalización de los contenidos y esa sutil censura emanada de los estereotipos culturales que simplifican la realidad o la endulzan. A este respecto, constata que lo que les interesa a los mass media de él es su imagen de poeta globetrotter, muy congraciable con el concepto de sociedad del espectáculo (Acción Fílmica, 2014).
} 
La expectativa de una repercusión, de una reacción pública que refleje la consumación de una comunicación real es muy potente en el autor y queda probada por cauces tales como los foros de Internet. Una repercusión que, de modo extremo, se refleja en dos reacciones opuestas: el ataque a su actividad o la admiración de su actividad, reacción positiva que le agrada por cuanto representa la sanción popular de haber construido una experiencia lírica o estética, mientras que las otras reacciones le confirman en su lectura política. Incluso le agrada que sea la gente quien le reconozca como poeta antes que una institución o academia, en su condición de artista popular. Este punto es curioso, pues nos delata dos dimensiones sociales de catalogación habituales. Por ejemplo, mientras que para una parte de la población Batania puede ser tildado de «poeta», para la alta cultura esa sanción se niega en buena parte por lo indecoroso o infame de su actividad; y mientras que para otra parte de la población Batania podría ser tildado de «cabrón», para la justicia también lo sería al encuadrar su actividad como delito, gracias a la progresiva criminalización del medio (Acción Fílmica, 2014). Además, ese reconocimiento popular a pie de calle supone saber distinguir su poesía social o política de lo que sería otro tipo de pintadas sociales o políticas más convencionales, al tocar la dimensión poética y salirse de la retórica reconocible como política (Veoguadatv, 2011). Desde The Beatles y el MarxismoLennonismo hasta hoy existe una gran dicotomía entre una retórica más «materialista-objetiva» y otra más «fantasiosa-subjetiva», en la que el dogma pierde su sentido de ser fuera de un aparato estético con pretensiones monolíticas o un sistema político-cultural que aspira al fin de la historia. La revolución ha de ser informal, pero la estética es la ética del arte: de nada vale un poeta comprometido, sea feminista, anarquista, universalista, antirracista, antifascista, anticapitalista, ecologista, pansexualista, sindicalista, etc., si no trata de cumplir «la exigencia fundamental del poema como arte» (Go!, 2015: 31). En resumen, como reza una de sus pintadas: «El pensamiento sin lirismo es un clítoris siempre seco».

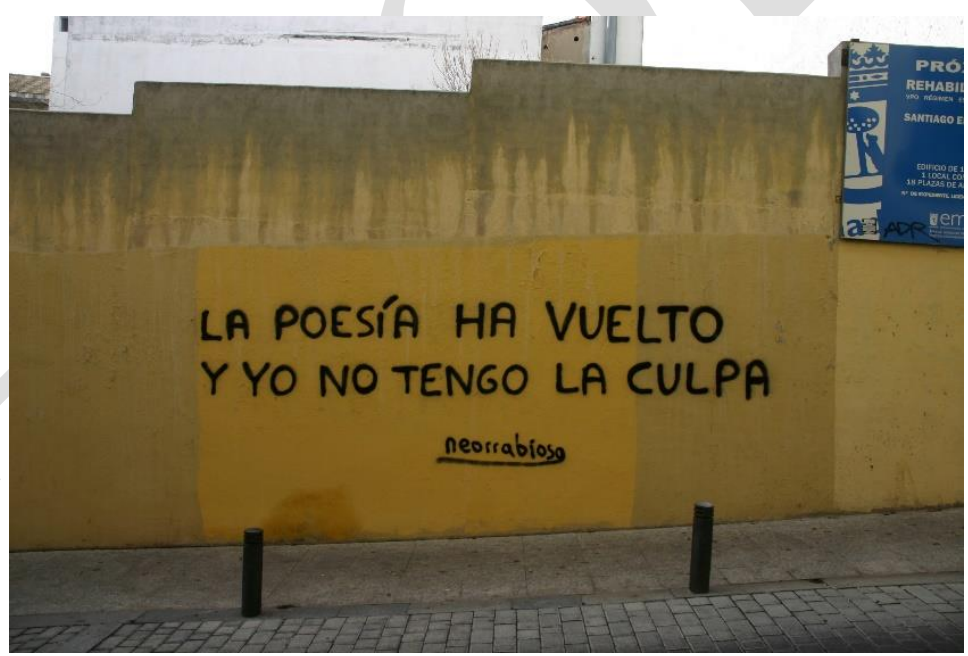

Fig. 6. Batania Neorrabioso. Diciembre de 2012. Fotografía de Guillermo de la Madrid, www.pintadoenlapared.com.
Esa necesidad de una confirmación o retroalimentación trasluce la viva emocionalidad que late en los grafiteros (artistas o no) y la percepción de su curso o carrera como una sucesión unitaria de experiencias. La vivencia de la pintada como práctica perseverante transita múltiples abanicos de sensaciones y estadios de vivencia, con independencia de las motivaciones concretas para emitir tal o cual mensaje, presentes en cada tipo de grafitero: expresión, autoafirmación, rebelión, notoriedad, reconocimiento, estatus, etc. (Brewer y Miller, 1990: 345-369; Brewer, 1992: 188; Gálvez y Figueroa, 2014: cap. 10). Esto es así, porque las motivaciones entre los que acometen la realización de grafitis parten 
básicamente de la necesidad de expresarse de modo notorio en un marco que o les es próximo o les sobrepasa, ajustándose sus estrategias según la necesidad de sortear obstáculos o batir retos. El diálogo entre motivaciones y objetivos genera las estrategias, coincidiendo, como vemos, soluciones similares entre autores distantes en el tiempo y el espacio. El grafiti, no lo olvidemos, es un constructo cultural que está sujeto a la sociodinámica de cada cultura urbana y la sociedad capitalista con su expansión y arraigo contribuye a generar un conjunto de fenómenos semejantes. La confrontación del grafitero con condicionantes tales como la oportunidad, la prestancia material, la moral pública, la disciplina social, la legalidad oficial, etc., imprimen carácter, mientras que los objetivos, por ejemplo, se sujetan a patrones propios de cada tipología grafitera y, en gran medida, a las convenciones suscritas tácitamente por cada comunidad de grafiteros en pos de un estatus y un legado.

Eso incide en que el deseo de expresarse y el deseo de dejar una huella del poeta urbano convergen en el deseo de impresionar, impactar sobre la fibra emocional del lector. Es más, lo ordinario del carácter extraordinario del grafiti, tanto ayuda a estar cerca de la gente como a que se aprecie como algo chocante, de ahí su impresión de «grito»o «rebeldía», ya recalcado por Bleck (la rata) como característica de la pintada urbana (Antena 3,1990$)^{34}$. No es una impresión casual, sino prevista y buscada en la poética del encuentro, de la sorpresa. Por eso Batania califica sus versos callejeros, en asociación con el concepto de shock, como poesía-susto, porque aparece sin avisar (García de Blas, 2011) y, evidentemente, espera otro «grito» de respuesta. El shock también funciona en el otro sentido, mediante la búsqueda de emociones, propias y ajenas, gracias a la exhibición pública y también a la acción furtiva. Esa consciencia hace que Batania asuma la exploración de la incertidumbre, del desequilibrio-motor que azuza la creatividad y apunte hacia la conexión entre arte y locura, y su final oposición a cualquier pretensión de perennidad, estabilidad o serenidad (Batania, 2014: 319, 326), aunque aspirara en algún momento a una ataraxia de hecho.

Por tanto, al igual que en otros actores grafiteros, se observa un reajuste de los motores y objetivos adecuado al desarrollo psicoevolutivo, el cúmulo de experiencias de cada individuo y la reflexión acerca de su quehacer, además del arraigo y desarrollo de cada escena en general. Batania admite la transformación de sus objetivos, que ya se intuye en su oscilación entre buscar una estabilidad apaciguadora y entregarse a un desequilibrio creador, y que residen también en la toma de conciencia de lo fútil de los patrones de medida, he ahí la razón de que abandone sus sueños de grandeza (Go!, 2015: 31), que era lo que le impulsaba hasta al menos 2011 (García de Blas, 2011). Así, su nueva percepción y enfoque llevan a que Batania considere como su horizonte una actitud más

\footnotetext{
34 La rebeldía en Batania tiene un punto romántico. Su objetivo no es la victoria, porque hasta la derrota es bella (sublimación del «no future» punki); lo que conecta con el carácter de la poesía, del grafiti, del gamberrismo, del chiste como resistencia. Al tiempo, reafirma la necesidad de la rebeldía como un motor hacia la utopía o una protección contra la distopía. El poeta o el artista rebeldes han de inspirar a los nuevos rebeldes, sin la pretensión de iluminar o convencer a los demás. Han de limitarse a exponer sus ideas, siempre sujetas a revisión. Frente a la academia, la vida; frente a la educación, el ejemplo; repunte de la lucha cínica entre Civilización y Naturaleza (Batania Neorrabioso, 2014: 323, 327).
} 
punki: «escribir buenos poemas en primer lugar y tocar los huevos a los fabricantes de muerte» (Go!, 2015: 31). O sea, maridar arte y rebeldía sin dejarse esclavizar por ninguna entelequia áulica.

Por último, comentaré que, consciente de la característica del grafiti como medio libre, a diferencia de propuestas como las de Acción Poética que, como todo arte público, plantea a priori una regulación, conservación y protección, sus pintadas son obras abiertas; Neorrabioso asume y fomenta

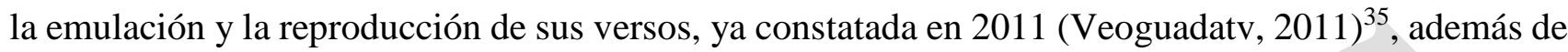
apreciar la contrapintada o intervención de sus versos ${ }^{36}$. Ese desapego se suma a su renuncia al control de su propia obra en papel, que pretende subvertir el ordenamiento mercantilista de la cultura y reclamar la autonomía de la cultura popular: «Cualquiera de estos poemas o prosas puede ser copiado, extractado o mejorado sin necesidad de pedir ningún permiso, citando la autoría o sin citarla, y para el uso que se desee» (Batania, 2014: 6). Planteamiento coherente en un partidario de la libre difusión de ideas y del derribo de las barreras y cortapisas que empobrecen o uniformizan la cultura popular y general (Batanania, 2014: 324), opositor a la Ley Sinde que apela a la libre circulación de contenidos en la Red, y que se declara «pirata» (Batania, 2014: 41). Cualquier exigencia por su parte de una potestad o derecho sobre sus pintadas carecería de sentido, salvo que asuma la necesidad de una reivindicación vinculada, más allá de los derechos morales de la propiedad intelectual, a la rentabilidad económica de una producción artística, y eso parece alejarse bastante de su propósito.

\section{Bibliografía}

ABARCA, J. (2010): El postgraffiti, su escenario y sus raíces: graffiti, punk, skate y contrapublicidad.

Madrid, Universidad Complutense de Madrid; en http://eprints.ucm.es/11419/ (última consulta, 21-6-2016).

ACCIÓN FÍlmiCA (2014): «Underground Project, 1.3 - Batania (Neorrabioso)», en https://www. youtube.com/watch?v=YZr3QVNzPEQ (última consulta, 21-6-2016).

Antena 3 (1990): «Graffiti: nueva forma de expresión», Noticias del Domingo.

ARIAS, F. (1977): Los graffiti: juego y subversión. Valencia, Lindes/Comunicación.

BATANIA NEORRABIOSO (2013): El amor es un ave sin nido que pone huevos en el aire. Madrid, edición del autor.

(2014): La poesía ha vuelto y yo no tengo la culpa. Madrid, edición del autor.

BESANÇON, J., ed. (1968): Les murs ont la parole. París, Claude Tchou.

\footnotetext{
35 Batania ha generado su propia corte de imitadores — que también los hay de modo ocasional y que se distinguen por reproducir o imitar con afán de exactitud sus pintadas personales, lo que él acepta como colaboración o cooperación- y de emuladores. Estos construyen un estilo distinguido de hacer las cosas, tanto en el campo gráfico como literario, como es el caso de Kikomoras en Móstoles o Alonso en Madrid. Lo que da por sentado el establecimiento general de germinaciones urbano-poéticas que germinan y florecen, atendiendo a la coyuntura política de cada momento y lugar.

${ }^{36}$ Batania con agrado resaltaba en su blog el caso de la pintada «Si escribo versos es porque no se escribir aviones», que otra persona alteró de este modo: «Si escribo versos es porque no se escribir haviones», resaltando el hecho de «no saber escribir», pero dándole también un aspecto más aéreo [http://neorrabioso.blogspot.com.es/2015/03/blog-post_25.html; última consulta, 21-6-2016].
} 
Brewer, D. D. (1992): «Hip Hop Graffiti Writers' Evaluations of Strategies to Control Illegal Graffiti», Human Organization, 51/2, pp. 188-196.

Brewer, D. D. - Miller, M. L. (1990): «Bombing and Burning: The Social Organization and Values of Hip Hop Writers», Deviant Behavior, 11, pp. 345-369.

Cressey, P. G. (1932): The Taxi Dance-Hall. Montclair, Patterson Smith, 1969.

Dufrenne, M. (1974): Art et politique. París, Union Générale d'Éditions.

FERNÁNDEZ ÁLVAREZ, Ó. (1994): «Diferentes concepciones en los estudios de antropología urbana», Estudios Humanísticos, Geografía, Historia y Arte, 16, pp. 245-269.

Figueroa SAAVEDRA, F. (2004): El graffiti universitario. Madrid, Talasa.

- (2006): Graphitfragen. Una mirada reflexiva sobre el Graffiti. Madrid, Minotauro Digital.

(2013a): «Paciencia, pan y tiempo: Panorámica histórico-social del grafiti de los presos de la Cárcel de Carabanchel», en Carmen ORTIZ, coord., Lugares de represión, paisajes de la memoria. La Cárcel de Carabanchel. Madrid, Catarata, pp. 275-308.

- (2013b): «Graffiti: un problema problematizado», en AA. VV., Madrid. Materia de debate 2003-2013. Madrid, Club de Debates Urbanos, vol. IV, pp. 373-401.

(2014): El grafiti de firma. Madrid, Minobitia.

Figueroa SaAvedra, F. - Gálvez Aparicio, F. (2002): Madrid Graffiti, 1982-1995. Málaga, Megamultimedia.

GÁlvez, F. - FigueroA, F. (2014): Firmas, muros y botes. Historia social y vivencial del Graffiti Autóctono. Madrid, edición de los autores.

Gan Bustos, F. (1978): La libertad del WC. Para una sociología del graffiti. Barcelona, Dopesa.

GÁndARA, L. (2002): Graffiti. Buenos Aires, Eudeba, 2007.

GARCÍA DE BLAS, E. (2011): «El grafiti poético “neorrabioso”. Un vizcaíno inunda Madrid de pintadas reivindicativas», El País (25-7-2011), en http://elpais.com/diario/2011/07/25/madrid/ 1311593062_850215.html (última consulta, 21-6-2016).

Go! (2015): «Entrevista a Batania Neorrabioso», Go! Pontevedra/Vigo, 80, p. 31.

HANNERZ, U. (1980): Exploración de la ciudad. Hacia una antropología urbana. México, Fondo de Cultura Económica, 1986.

HAUSER, A. (1957): Introducción a la Historia del Arte. Madrid, Guadarrama, 1973.

HERnÁndeZ, M. (2013): «Batania Neorrabioso, el poeta hecho a sí mismo», Baldosas Rojas, en http://www.baldosasrojas.com/index.php/literatura/autores/item/239-batania-neorrabioso-

poesia/239-batania-neorrabioso-poesia (última consulta, 21-6-2016).

INDIO JUAN, comp. (2001): Las frases del Metro. Madrid, Ediciones GPS.

KOZAK, C. (2004): Contra la pared. Buenos Aires, Libros de Rojas.

KOZAK, C. - ISTVAN - FlOYD - BOMBINI, G. (1990): Las paredes limpias no dicen nada. Buenos Aires, Libros del Quirquincho.

PAREDES, J. (1999): Grafiteadas. La Paz, Mujeres Creando.

PARK, R. E. (1952): Human Communities. Glencoe, Free Press. 
POPPER, F. (1980): Arte, acción y participación. El artista y la creatividad hoy. Madrid, Akal, 1989.

RodríGUEZ LEAL, S., comp. (2002): De Vallecas al Valle del Kas. Los años vividos 20-11-75 / 19-0186. Madrid, Radio Vallekas.

TELEK (2012): La noche tuerta 14-02-2012- Neorrabioso, en https://www.youtube.com/watch?v= O2scAKitH_I (última consulta, 21-6-2016).

URANGA, I. (2012): «Batania: versos de un contrapaís neorrabioso», Urbesalvaje, en https://urbesalvaje.wordpress.com/2012/04/04/batania-versos-de-un-contrapais-neorrabioso/ (última consulta, 21-6-2016).

VeOguAdATV (2011): «Con versando con Batania», Veoguadatv.com, en https://www.youtube.com/ watch?v=CbZ8zAKm4o8 (última consulta, 21-6-2016). 